\title{
費用便益分析を用いた病院の適正配置評価手法に関する研究 A STUDY ON A METHOD FOR EVALUATING ALLOCATION OF HOSPITALS USING COST-BENEFIT ANALYSIS
}

\author{
今泉恭一*, 浅見泰司** \\ Kyoichi IMAIZUMI and Yasushi ASAMI
}

\begin{abstract}
A method for evaluating allocation of hospitals in a region is developed using cost-benefit analysis. This method can be applied to the problem of integrating hospitals for reorganization of regional medical systems. Based on a questionnaire survey, the hospital choice behavior of patients is analyzed with the logit models, in which the distance and travel cost from a residential place to a hospital, the number of beds, and the waiting time are explanatory variables for each type of sickness and injury. The utility of hospital for the patients is converted into monetary term. Relative advantage of alternative sites for allocation of hospitals can be assessed through this result and one such case is exemplified.
\end{abstract}

\author{
Keywords : Hospital, Allocation Evaluation, Facility Choice Behavior, Logit Model \\ Cost-Benefit Analysis \\ 病院施設, 配置評価, 施設選択行動, ロジットモデル，費用便益分析
}

1.はじめに

(1) 背景・目的

急速な高龄化社会の進行や医療の高度化等により，国民医療費は 年々増大を続计る一方で, 経済成長との不均衡は拡大している。厚 生白書で述べられているように「21世紀の少子高齢化社会において も，総ての国民が安心して良質な医療サービスを受けることができ， しかも効率的である医療・保険制度への転換」が緊急の課題となっ ている。特に医療提供体制について見ると「医療機関の機能分担と 連携を進める」という方針のもと，公的医療機関非1）等の病院の統 廃合が具体的に動き始めている。一方, 病院は, 阪神・淡路大震災 の時にも指摘されたように, 大規模災害が発生した場合に機能すべ き地域の重要な拠点施設拄2)である。従って地域における医療体制 の再編成を検討する際には，平常時の住民に対する利便性の維持・ 向上や社会的な医療資源の効率的活用に加えて, 災害時の医療提供 能力も考慮される必要がある。特に公的医療機関は，社会資本の一 環であり，種々の社会的な便益と費用を考慮して，統廃合に伴う投 資の有効性を評価しなくてはならないだろう。病院の統廃合に伴う 便益・費用を総合的に捉え，地域における施設配置計画を評価する ためには，対象項目の異なる評価単位を統一的に扱う必要がある。 そこで本報では, 研究の第一段階として平常時のみを対象に, 公
共経済学より発展した費用便益分析辣 3) の考え方を適用して, 病院 の施設配置計画を貨幣タームで評価するための方法論を提案する。 病院については, 公表データ上の制約等が配置評価に対する費用便 益分析適用の障壁となっているが, ここでは公表データを最大限活 用する形で，医療関係者を交えた独自の調査も実施し，更にモデル 上の工夫を施して本手法の適用性を検討する。本手法を用いれば, 例えば, 統廃合後の移転候補地が複数箇所あった場合, 地域にとっ てどの候補地を選定したらよいのかといった問題に対し，関係者が 合意形成を図りながら意思決定を行っていくことが容易になると考 えられる。本報で展開する基本的な手順は，以下の 2 段階である。 (1)独自調査を基に, 貨幣タームでの便益計測を可能とする傷病者 の施設選択モデルを作成する。

(2)上記モデル及び公表データ等を用いて,病院施設の地域配置計 画を費用便益評価するための方法を提示する。

なお本報では，二次医療圈内旺4）における一般病院と診療所暗 5) (双方を併せて以下, 医療施設)の外来及び入院医療を対象としてお り，医療圈が広域に互る傷病（全県が一圏域である精神疾患等）は 考慮していない。

(2) 既往の研究

上記(1)施設選択行動の予測モデルについては,一般的に,ハフ・
* 鹿島建設広報室 工修, M.C.P.

** 東京大学大学院工学系研究科都市工学専攻 助教授・Ph. D
Public Relations Office, Kajima Corporation, M. Eng., M. City Planning Assoc. Prof., Dept. of Urban Engineering, Univ. of Tokyo, Ph. D. 
モデル, エントロピー・モデル等の空間相互作用モデル3４４）開発 されている。これらのモデルは「利用者と施設間の距離」及び「施 設の魅力度」の関数として, 利用者による施設の選択確率が得られ るもので, 主としてOD表形式の集計デー夕に対して用いられる。従 来, 医療施設に対しても，これらのモデルが適用される場面が多い。 一方, 近年, 個人の選択行動を捉えモデルを精緻化する方向として, 非集計行動モデルの施設選択への適用が試みられている。非集計行 動モデルの一つであるロジットモデル註6) の医療施設への適用につ いてはCohen $5^{5)}$, 佐藤ら ${ }^{6)}$, アシシアら ${ }^{7)}$ などが研究成果を発表 している。しかし各々の研究の目的上，ロジットモデルで推定した 患者の効用に関し，貨幣価值換算を指向した検討はなされていない。

次に，前述(2)に関係する各種施設の配置評価法については，柏原 による地域施設の配置手法を論じた研究いをはじめ, 過去に多くの 成果がある。近年は「平均利用距離」といった単一の指標を用いた 評価手法から, 複数指標を対象に多目的最適化問題での合理的な解 を求めようとする多目的計画法に研究の焦点が移ってきている。更 に最近では，青木らによる遺伝的アルゴリズム（Genetic Algorithm: GA）を用いた報告 ${ }^{8)}$ ，山下らによる GAを用いた高齡者在宅福祉 サービス供給に関する報告 ${ }^{9)}$ ，横田による DEA（Data Envelopment Analysis）を用いた高齢者福祉施設に関する報告10)等が, 新たな研 究動向として挙げられる。特に医療施設の配置評価について見てみ ると，横田が上述の多目的計画法に関し，荷重和型，最小成分最適 型, $\varepsilon$ - 制約式型, 階層分析法といった種々の方法論の適用を示し ている1112)。しかしながら，昨今，プロジェクト評価の実務分野で 利用が活発化してきている費用便益分析については，既公表のデー タ上の制約もあって,医療施設の配置評価に対する研究事例はない。

\section{2. 評価方法の概念}

\section{(1) 適用ケースの想定}

病院の統廃合に当たっては, 既存入院患者への医療上の配慮, 資 金調達の有利さ等の面から, 新たな用地を取得して病院を移転する ケースが多い。そこで今回の研究対象とする手法の適用範囲は, 複 数の移転候補地の中から社会的純便益（総便益と総費用との差）が 最も大きい敷地を選定するという場合を想定する。配置評価の条件 を簡便化するために, 全ての移転候補地には, 道路等のインフラが 既に整備されているものとすると, 施設移転に伴い社会全体で変化 する主要な便益・費用の項目は表1のように考えられる。

まず事業者側について見ると, 病院の統廃合は，事業の運営維持 费（管理コスト）の削減, 利用者に対するより快適な診療空間の提 供（例. 一病床当たりの床面積の拡大）等を狙って行われるもので ある。ただし表 1 において，敷地の立地場所によって便益・費用の 值が変動する項目は, 来院患者数の影響を受ける「事業収入」, 事業

\section{表 1 施設移転に伴って变化する主な便益。費用項目}

\begin{tabular}{|l|l|l|}
\hline 主 体 & \multicolumn{1}{|c|}{ 便益項目 } & \multicolumn{1}{|c|}{ 費用項目 } \\
\hline 事業者 & $\begin{array}{l}\text { ·現有敷地の売却収入 } \\
\text { ·事業収入 }\end{array}$ & $\begin{array}{l}\text { ·事業費 (用地取得費、建設費等) } \\
\text { ·運営維持費 (人件費、光熱費等) }\end{array}$ \\
\hline 利用者 & $\begin{array}{l}\text { ·傷病からの回復 } \\
\text { ·院内環境の快適性向上 }\end{array}$ & $\begin{array}{l}\text { ·病院への移動コス卜 } \\
\text { ·医療費（自己負担金、健康保険） } \\
\text { ·診療時間及び待ち時間 }\end{array}$ \\
\hline
\end{tabular}

費中の「用地取得費」及び運営・維持費中の「病院スタッフの移動 コスト（交通費と移動時間）」が主なものであると言える。

次に利用者側を見ると，家族の面会等を考慮した上での「居住 地・病院間の移動コスト」が, 敷地の立地場所によって影響を受け る直接的な項目である。「病院での待ち時間」については, 施設の運 営方法に関わる部分の他に, 利用者の施設選択行動の結果である来 院患者数の影響がある。選択行動の一つの説明因子が移動距離 6) 7) 11) 12)であることを考えると，「待ち時間」は間接的に立地場所の影 響を受ける項目であると言える。事業者及び利用者の双方について， 上記以外の項目は, 病院の運営体制や建築内容自体に関わるもので あり，本質的に立地場所による影響を受けるものではない。

従って基本的に,複数の候補地より最適な移転場所を選定しよう とする今回のケースでは，利用者側の「移動コスト」及び「待ち時 間」について，消費者余剩を含めた効用水準の増加もしくは減少分 を地域の総和として貨幣価値換算し, 更に事丵者側の便益・費用で ある「事業収入」「用地取得費」及び「病院スタッフの移動コスト」 を考應して, プロジェクトの評価をすればよいこととなる。その結 果, 各移転候補地間の社会的純便益の大小関係を比較することで, 候補地選定に対する倒先順位を提示することが可能となる。

（2）病院選択行動のモデル化

地域内の病院配置が変わることによって, 各病院の医療需要に変 化が生じる。移転候補地間で费用便益の比較を行うためには, より 正確に地域における利用者の病院選択行動を推定する必要があり, 本研究では，個人の選択行動を記述することができる非集計行動モ デルを採用することとした。

一般に, 施設の配置状況によって, 施設選択率が変化する場合に は，その効用はランダム効用理論13)を用いて計測することができ

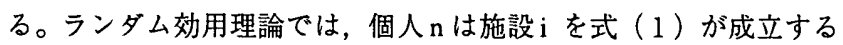
時に選択すると考える。

$$
V_{i}\left(a_{i}, b_{n i}, c_{n}\right)+\varepsilon_{n i} \geq V_{j}\left(a_{j}, b_{n j}, c_{n}\right)+\varepsilon_{n j} \quad \forall j \neq i
$$

ここで，Vは効用の確定項，a は施設の質(魅力度)， $\mathrm{b}$ は施設を 訪れるために要する費用, $\mathrm{c}$ は個人の属性, $\varepsilon$ はランダムな誤差項 である。誤差項の分布がガンベル分布であるとすると, 個人がM個 の代替的な目的地から目的地 $\mathrm{i}$ を選択する確率 $\mathrm{P}(\mathrm{i})$ は式（2）のよ うに表すことができる。

$$
\mathrm{P}(\mathrm{i})=\exp \left(\mathrm{V}_{\mathrm{i}}\right) / \sum_{\mathrm{j}=1}^{\mathrm{M}} \exp \left(\mathrm{V}_{\mathrm{j}}\right)
$$

式（2）は多項ロジットモデル（Multinominal Logit：以下, MNL モデル） ${ }^{14 ）}$ と呼ばれている。MNLモデルにおいて施設選択に関す る利用者の効用の確定項は, 上記説明変数 $\mathrm{a}, \mathrm{b}, \mathrm{c}$ の線形和として 定義される。ここで外来診療の対象となる伤病では, 利用者が「医 療施設に行かず自宅で療養する」というケースが考えられる。この 場合は，MNLモデルにおいて「施設には行かない」という選択 肢を施設選択肢群に含めて，並列的に分析する方法を採用した。 （3）利用者便益の計測方法

病院選択モデルを用いた利用者便益の推計に関しては, 消費 者余㮃の概念を用いて最大効用の期待值により求める方法を 採った。MNLモデルによる需要関数から得られる最大効用の期 待值について, $\mathrm{E}_{0}$ は現状, $\mathrm{E}_{1}$ は病院の移転後を示すものとする。 $\mathrm{C}_{0}, \mathrm{C}_{1}$ を各々の選択肢集合, $\mathrm{V}_{\mathrm{j}}^{0}, \mathrm{~V}_{\mathrm{j}}^{1}$ を各々の効用の確定項とする と, $\mathrm{E}_{0}$ 及び $\mathrm{E}_{1}$ は式 (3) 及び式 (4) で与えられる。 ${ }^{14)}$ 


$$
\begin{aligned}
& E_{0}=\ln \sum_{j \in C_{1}} \exp \left(V_{j}^{0}\right) \\
& E_{1}=\ln \sum_{j \in C_{1}} \exp \left(V_{j}^{1}\right)
\end{aligned}
$$

次に等価的偏差 (Equivalent Variation) を考えこれを各選択肢に

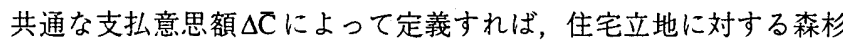
ら 15) 及び鉄道ネットワークに対する屋井ら ${ }^{16)}$ の方法を本問題に適 用して $\Delta \bar{C}$ は式 (5) の様に示すことができる。ここで $\beta$ は病院選択 モデル中の費用パラメータである（論理的に $\beta<0 ） 。$

$\Delta \bar{C}=\left(E_{1}-E_{0}\right) /(-\beta)$

従って地域全体における便益 (NB:Net Benefit)の推計は, 式 (5) で得られた $\Delta \mathrm{C}$ に傷病者数 $\mathrm{N}$ 乗じて算出することができる。

$\mathrm{NB}=\mathrm{N} \Delta \overline{\mathrm{C}}$

\section{3. 病院選択モデルの構築}

（1）傷病のグループ化

選択行動モデルを構築するために, 本研究では次項で述べるアン ケート調查を実施することとした。まず患者の受療行為を少数の㐮 ブモデルで表現する目的で，対象とする傷病をグループ化した。グ ループ化する際の仮定として「患者が感じる傷病の重さと治療費の 大小には相関があり,治療費の確率的な発生パターンが似ていれば, 医療施設の選択行動も類似する」と考えた。傷病の分類は，一般的 にデータの入手が可能であること，及び他の統計データと整合性が あることを考慮して傷病大分類暗门を用いた。治療費の発生パター ンは文献 [17］の「一日当たりの診療行為点数」裎8) を基に頻度分 布を作成して分析を行うこととした。図 1 に，当該頻度分布とその 際用いた診療点数の区分を，外来医療を例として示す。

本報では「一日当たりの診療行為点数」の頻 度分布形状の類似性により傷病をグループ化す る際，階層的クラスター分析 ${ }^{19)}$ を用いた。クラ スター分析は, 類似性の高いもの同士をグルー ピングする手法であり，(1)類似度に対する指標, 及び(2)グルーピングするための方法の 2 点で分 類される。ここでは傷病大分類に基づく傷病（以 下, 傷病区分) 間の分布形状の類似度に関する指 標，すなわち分類項目間の距離としてカイ自乗 值非9)を用い，またグルーピング方法については 最長距離法社10)を適用した。診療点数の相対的な 高低により,外来·入院医療別に傷病区分につい てグルーピングした結果辣11)を, デンドログラム として図2の（a）（b）に示す。ここで両図の 横軸は，傷病区分同士の結合距離をその最高距 離で除した值の100倍をスケールとしている。外 来診療については「一日当たりの診療行為点数」に加えて, 傷病が 急性か慢性かにより施設選択行動が異なるものと考え, 図 $2(\mathrm{a})$ 中 において，慢性疾患の割合が高い「内分泌等」を、グループを分け て独立したサブモデルとして取り扱うこととした。

(2) アンケート調査の概要

モデル構築に適合するデータについては，一般的に個人の行動を 取り扱ったものがないため，仮想的な質問を設定したアンケート調 査を独自に実施した。アンケートは，東京及びその隣接地域に居住 する, 著者の所属機関等の勤務者, 学生, 及びその家族を対象にし
て約 400 枚を配布した。実施内容は，以下の通りである。

(1)図 2 でグルーピングした傷病区分のサブモデル（以下，タイプ $1 \sim 5$ ) 毎に, 診療点数階級別の頻度分布における代表値とし て各中央値を求めた。

(2)医療関係者と話し合い, タイプ1〜 5 の各々に対して, 上記(1) で求めた診療点数の中央值に概ね近い,一般的に認識できる傷 病例を表 2 のように具体的に設定した。

(3)上記(2)で設定した各傷病に対し「その病気になった場合にどの ような行動をとるか」という仮想的な質問社12)を回答者に提示 した。前提として居住地で傷病にかかったと想定し回答して欲 しい旨を記した。

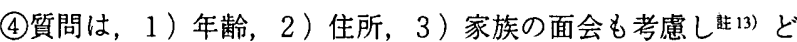
この医療施設に行くか，4）何故その施設を選択したか，5） 交通手段は何を使用する か，6）施設での待ち時 間はどの程度を考えてい るか等である。

回答内容の欠落や施設選択 理由が「以前住んでいた場所 からの利用の継続」、等の場合 を回収データから除外した結 果, 有効回答数は, $255 \sim 308$ 件（傷病タイプによって異な る)となった。タイプ1を例に 二次医療圈ごとに見た回答者 数の分布を図 3 に示す。

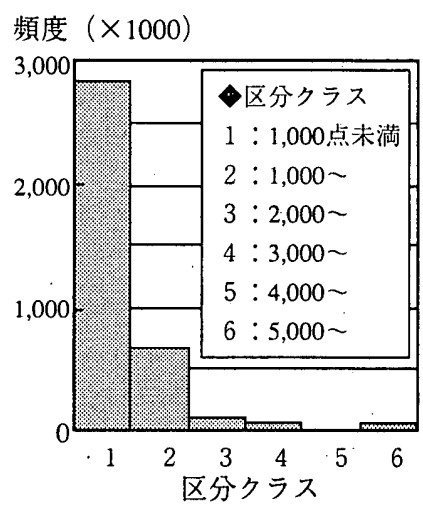

図 1 診療行為点数の頻度分布 (消化器系疾患・外来医療の例)
結合距離／最高距離 $\times 100$

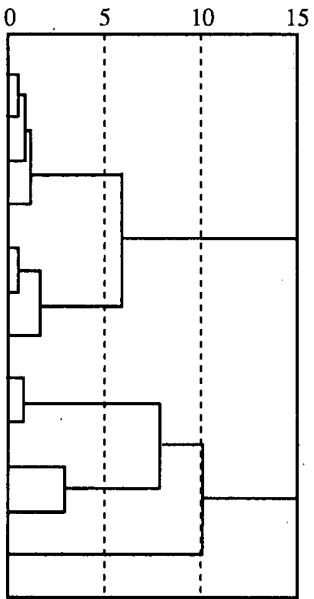

（a）外来医療

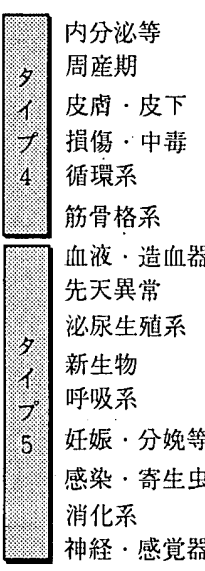

結合距離 / 最高距離 $\times 100$

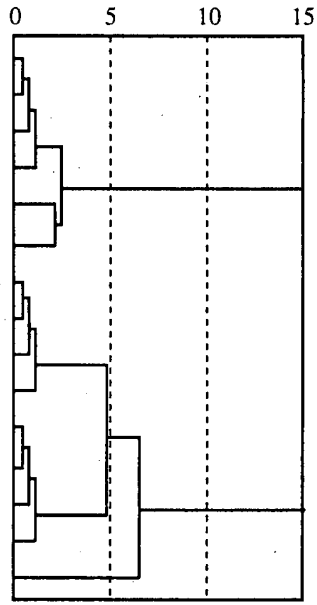

(b) 入院医療
図 2 傷病区分のデンドログラム社?

\begin{tabular}{|c|c|c|c|c|c|c|}
\hline \multirow{2}{*}{$\begin{array}{l}\text { 医療 } \\
\text { 種別 }\end{array}$} & \multicolumn{3}{|c|}{ 診療点数の高い傷病群 } & \multicolumn{3}{|c|}{ 診療点数の低い傷病群 } \\
\hline & タイプ & 点数 $/$ 日 & 傷病例 & タイプ & 点数 $/$ 日 & 傷病例 \\
\hline 外来 & 2 & \multirow{2}{*}{1000} & 急性胃腸炎 & \multirow{2}{*}{1} & \multirow{2}{*}{500} & \multirow{2}{*}{$\begin{array}{l}\text { 高熱を伴 } \\
\text { 感膡 }\end{array}$} \\
\hline 医療 & 3 & & 糖尿病 & & & \\
\hline $\begin{array}{l}\text { 入院 } \\
\text { 医療 }\end{array}$ & 5 & 3000 & 急性肝炎 & 4 & 2000 & \begin{tabular}{|l} 
軽微な手術 \\
を伴う骨折
\end{tabular} \\
\hline
\end{tabular}

表 2 傷病の設定 
（3）ロジットモデルによる分析

医療施設に関する過去の文献5６６） 〕参考にして，モデルにお ける選択肢の魅力度の变数としては一般病床数を, また費用の増大 に伴う抵抗として，居住地から病院までの往復移動距離及び往復交 通費，病院における待ち時間（外来診療のみ）を選定した。また利 用者の属性としては年齢区分を取り上げることとした。ここで待ち 時間については「アンケート回答の期待待ち時間は世評等を通じて 合理的に判断されており実待ち時間を反映している」という仮定を 置いた。往復交通费は，式（5）で示した便益計測の際に必要とな る費用パラメータ $\beta$ に対応する説明変数として探用胜14) したもので ある。表 3 にモデルにおける説明変数をまとめる。ただし同表より， タイプ3では「非選択の効用」を，タイプ 4 及び 5 では「非選択の 効用」「20床末満の診療所」及び「待ち時間」を除いた变数の線形 和としてモデル検討を行った。式（2）に示す施設の選択肢集合 $\mathrm{M}$ については，以下の通り設定した。

(1)タイプ1及び2（急性の外来医療）については, 回答者の属す る市区町村に立地する全ての一般病院 ${ }^{20)} に$ ，同じ市区町村内 に居住する回答者が一人でも選択した医療施設を付加した。

(2)タイプ 3 5 (慢性の外来医療及び入院医療) では, 回答者の

属する二次医療圈内の全ての一般病院に, 同じ二次医療圈内に

居住する回答者が一人でも選択した医療施設を付加した。

回答者一人当たりで見た代替的な選択施設数 $|\mathrm{M}|$ |の平均值と標 準偏差は各々，上記(1)の場合は 16.9 と 10.1, 上記(2)の場合は76.2 と 22.3 である。試行的に行ったパラメータ推定において，年齡区分に

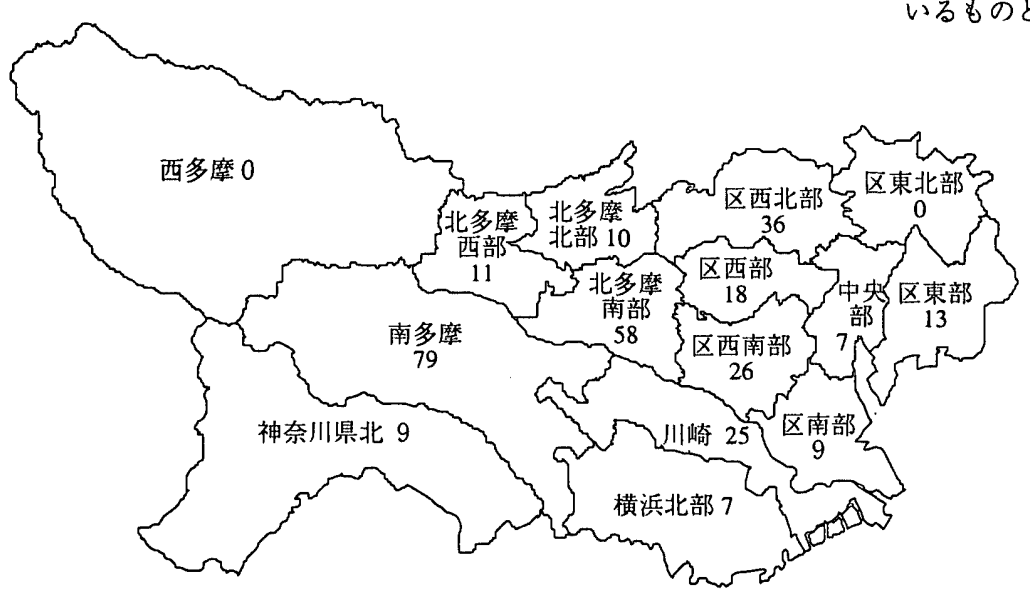

図 3 二次医療圈毎の回答者数の分布（タイプ1の例）

表 3 説明変数の設定

\begin{tabular}{|c|c|c|}
\hline カテゴリー & 説明変数 & 内 \\
\hline \multirow{3}{*}{ 病床規模 } & BD_20 & 20床圭泗（ダミー変数） \\
\hline & BD_200 & 20～200床圭満（ダミー変数） \\
\hline & BD_500 & 200～500床圭満（ダミー変数） \\
\hline 移動距離趾16 & DIS & 居住地から病院までの往復道路距離 $(\mathrm{m})$ \\
\hline 交通费明17) & $\operatorname{cosT}$ & 居住地から病院までの往復交通費（円） \\
\hline 待ち時間 ${ }^{\text {社18 }}$ & WAIT & 病院での期待待ち時間（分） \\
\hline \multirow{2}{*}{ 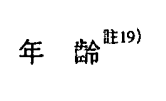 } & AGE_25 & 25歳圭満（ダミー変数） \\
\hline & AGE_55 & 25〜55歳满（ダミー変数） \\
\hline 非選択の効用 & NO_GO & 施設に行かない場合「1」（ダミー变数） \\
\hline
\end{tabular}

関しては, タイプ1〜5の全ケースで統計的有意性が示されなかっ たため,これらの変数をモデルから除外した暗20)。最終的に得られた 結果を表 4 にまとめる。本結果について以下のことが指摘できる。

(1)タイプ1〜 5に対する効用の推定式はカイ自乗検定の結果䊀21), $1 \%$ 水準で全て統計的に有意となった。

(2)パラメータの符号に着目すると,タイプ1〜 5 の全てにおいて 費用増大に伴う抵抗である移動距離, 交通費, 待ち時間は全て 負の係数となっており，論理的な説明力を有している。

(3)全タイプの中では, タイプ1が最も移動距離, 及び交通費の増 大に対する抵抗値が大きく,近くて交通費用のかからない施設 を選択しようとする傾向が表れている。

(4)病床規模についてパラメータの数值を見ると,タイプ1では小 規模な医療施設を選択する傾向にあるが,他の 4 タイプではよ り規模の大きな施設を選ほうとしていることが読みとれる。 (5)全ての推定式について尤度比 $\rho^{2}$ は0.2以上であり,データに对 して十分高い適合度を持つものと判断できる ${ }^{14) 。 ~}$

(6)式（2）を用いて，推定した確率値の最大となる医療施設（非 選択を含む) が選択結果であるとみなし，実際の回答と比較し た。その結果，全てのタイプで $40 \%$ 以上の的中率を示しでお り，概ね良好な推定モデルであると言える。

\section{4. 邀用便益分析の観点からの配跕計画評価}

\section{(1) 便益計測の全体フロー}

公表データに加え，前章で提示した内容の関連データが得られて いるものとして, 病院の配置計画を費用便益分析の観点から評洒す るための流れを図 4 に示し，便益計測の各手順を以下 に述べる(丸数字は図4の項目を示す)。ただしここで は, 施設移転に伴って変化する事業者側の便益·費用額 は別途与えられるものとして, 利用者側の便益·費用の みを計測の対象とした。なお便益計測の具体例につい ては，次節のシミュレーションを通じて提示する。 a . 最大効用期待値の算出（図 4 の [A]）

前章で分析した施設選択モデルを用い，病院の移転 前（現状）と移転後（計画）の各々について，伤病タイ プ毎に各個人における最大効用の期待值を求める。

第一に，モデルに対する基本データとして，各選択可 能施設の病床デー夕 (2) と待ち時間デー夕 (3)), 及 び施設並びに居住者の住所データ（1) を準備する。施 設に関する病床データと住所データは文献 [20], 待ち 時間データは独自のアンケート調査等から狡得する。 居住者の住所については, 国势統計区（町丁目レベル； 以下，地区）等に細分化し，各地区の重心に当該地区の 全夜間人口が集中する，すなわち同一地区に属する全 居住者は, 地区の重心に居住するものと仮定する。その 上で, 各居住地とそれぞれの選択可能施設との往復道 路距離 (4) を算出する。居住地から選択可能施設へ移 動するための交通手段 (5) は, 上記同様, 独自のアン ケート調査等を行い, 地域における移動交通手段の選 択ルールや手段分担率を設定した上で, 各居住地・施設 間の平均往復交通費（6）を算出する。 次に各傷病タイプに対して, 上記で準備・算出した(2) 
表 4 パラメータの推定結果

\begin{tabular}{|c|c|c|c|c|c|}
\hline \multirow[b]{2}{*}{ 説明変数 } & \multicolumn{5}{|c|}{ 各説明変数のパラメータ } \\
\hline & $\begin{array}{c}\text { タイプ } 1 \\
\mathrm{~N}=308\end{array}$ & $\begin{array}{c}\text { タイプ } 2 \\
\mathrm{~N}=295\end{array}$ & $\begin{array}{c}\text { タイプ } 3 \\
\mathrm{~N}=257\end{array}$ & $\begin{array}{c}\text { タイプ } 4 \\
\mathrm{~N}=255\end{array}$ & $\begin{array}{l}\text { タイプ } 5 \\
\mathrm{~N}=255\end{array}$ \\
\hline 定数 & $\begin{array}{c}-1.686^{*} \\
(0.682)\end{array}$ & $\begin{array}{c}0.299 \\
(0.307) \\
\end{array}$ & $\begin{array}{c}0.217 \\
(0.243) \\
\end{array}$ & $\begin{array}{c}0.415^{*} \\
(0.179)\end{array}$ & $\begin{array}{c}0.0732 \\
(0.180) \\
\end{array}$ \\
\hline BD_20 & $\begin{array}{c}0.893 \\
(0.618)\end{array}$ & $\begin{array}{c}-1.746^{*} \\
(0.242)\end{array}$ & $\begin{array}{l}-3.243^{*} \\
(0.241)\end{array}$ & - & - \\
\hline BD_200 & $\begin{array}{c}0.448 \\
(0.640)\end{array}$ & $\begin{array}{c}-1.329^{*} \\
(0.257)\end{array}$ & $\begin{array}{l}-1.438^{*} \\
(0.206)\end{array}$ & $\begin{array}{l}-1.780^{*} \\
(0.199)\end{array}$ & $\begin{array}{l}-1.429^{*} \\
(0.196)\end{array}$ \\
\hline BD_500 & $\begin{array}{c}0.428 \\
(0.679) \\
\end{array}$ & $\begin{array}{c}-0.563^{*} \\
(0.251) \\
\end{array}$ & $\begin{array}{c}-0.669^{*} \\
(0.187) \\
\end{array}$ & $\begin{array}{l}-0.771^{*} \\
(0.169) \\
\end{array}$ & $\begin{array}{c}-0.508^{*} \\
(0.171) \\
\end{array}$ \\
\hline DIS & $\begin{array}{c}-0.000405^{*} \\
(0.000069)\end{array}$ & $\begin{array}{c}-0.000306^{*} \\
(0.000024)\end{array}$ & $\begin{array}{l}-0.000150^{*} \\
(0.000015)\end{array}$ & $\begin{array}{c}-0.000170^{*} \\
(0.000014)\end{array}$ & $\begin{array}{c}-0.000170^{*} \\
(0.000015)\end{array}$ \\
\hline COST & $\begin{array}{c}-0.00223^{*} \\
(0.000733)\end{array}$ & $\begin{array}{l}-0.000322^{*} \\
(0.000078)\end{array}$ & $\begin{array}{c}-0.00163 \text { * } \\
(0.000259)\end{array}$ & $\begin{array}{l}-0.000143^{*} \\
(0.000046)\end{array}$ & $\begin{array}{l}-0.000071^{*} \\
(0.000022)\end{array}$ \\
\hline WAIT & $\begin{array}{c}-0.00486 \\
(0.00570)\end{array}$ & $\begin{array}{c}-0.00228 \\
(0.00274)\end{array}$ & $\begin{array}{c}-0.00254 \\
(0.00239)\end{array}$ & - & - \\
\hline NO_GO & $\begin{array}{c}1.830^{*} \\
(0.272)\end{array}$ & $\begin{array}{c}0.182 \\
(0.219)\end{array}$ & - & - & - \\
\hline$\overline{\rho^{2}}$ & 0.543 & 0.255 & 0.265 & 0.280 & 0.259 \\
\hline 的中率\% & 60.7 & 40.3 & 47.9 & 49.8 & 47.8 \\
\hline カイ自乗 & 1315.1 & 587.81 & 523.57 & 366.43 & 320.61 \\
\hline 自由度 & 7 & 7 & 6 & 4 & 4 \\
\hline
\end{tabular}

註）上段 $\mathrm{N}$ はデー夕数。*は1\%水準で有意；括弧内は標準誤差。

(3)(4)(6)のデータを施設選択モデル（7)）に入力し，地区毎に傷病者 一人当たりの施設別効用値（8）を計算する。更に当該効用値に対 して式 (3) 及び (4) を適用し, 地区毎の一人当たりの最大効用 の期待値（9）を求める。

\section{b . 年間延べ傷病者数の算定（図 4 の [B]）}

第一に, タイプ毎の地区別・1日当たりの傷病者数（13）を算出 する。タイプ 3〜 5については，傷病者は必ず医療施設を訪れるも のとしているので, 傷病者数は受療者数に等しいと考えられる。こ の場合，1日当たりの受療者数は, 各地区の夜間人口 (11) に対し, 文献 [21] の受療率（人口 10 万対・1日当たり，入院外来別，傷病 分類別：(12)をを乗じて算出する。一方，タイプ1及び 2 については 「医療施設へ行かず自宅療養する」という傷病者がいるものと仮定し ており，以下の方法を用いて，タイプ毎の地区別・1日当たりの傷

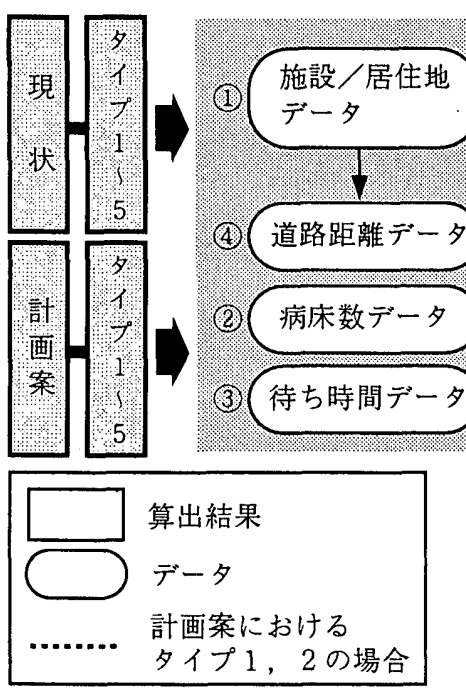

図 4 費用便益分析を適用した配置評価の流れ
病者数を算定する必要がある。

1) 現状について, 施設選択モデルからの効 用値に対し式（2）を適用して，地区別に 「施設に行く」確率（@）を求める。

2 ) 各地区の夜間人口に受療率21)を掛计合わ せ，更に上記 1 ）において算出した確率値 で除すことにより「施設に行かない」患者 を含めた地区別の全傷病者数を推定する。 次に，年間当たりの延べ訪問回数（迆）を算 出する。タイプ 1 3 (外来医療)では医療施 設の平均開業日数（年間 295 日）を延べ訪問回 数として用いる。またタイプ 4 及び 5 (久院医 療）では 365 日を平均在院日数（タイプ 4 は 27 日, タイプ5は19日) 21)で除した值，すなわち 一床当たりの年間延べ患者数をもって延べ訪問 回数と考える。最後に，1日当たりの傷病者数 と年間延べ訪問回数を地区別・タイプ別に掛け 合わせ, 年間延べ傷病者数（15）を算出する。 c. 純便益額の算出（図 4 の [C]）

利用者の純便益は, 式 (5) に基づいて算出 することができる。まず, 病院移転後と移転前 の各々について, 上記 $a, b て ゙$ 求めた一人当たりの最大効用の期待 値と年間延べ傷病者数をタイプ別・地区別に掛け合わせ, 地域にお ける年間の効用値を算出する。次に, タイプ別・地区別に, 消費者 余剩の増加分, すなわち移転後と移転前の効用值の差を求め, 当該 効用値の差を同一タイプに対する施設選択モデルの交通費用パラ メータによって除すことで, 年間純便益額（16）として貨幣価値に 換算する。

\section{（2）シミュレーションの概要}

事例として, 施設選択モデル作成の際にアンケート調査を実施し た南多摩二次医療圈を取り上げ，前節で示した基本的な手順迹22)に 則ってシミュレーションを行った。シミュレーションの条件を表 5 に, 病院の配置状況を図 5 に示す。なお医療費は, 移転の前後で変 わらないものと想定した。当該二次医療圈域は夜間人口約 120 万人 を有し，10万人当たりの病床数（991床）及び 1 病院当たりの平均 病床数 (198床) ${ }^{20)}$ は, 全国的に見て概ね平均的な地域である。 現状の病院配置状況を見ると,病院の数は全体的に地域中央部 に集まっているが, 200床以上の病院（23箇所）は地域に比較 的分散して立地している。シミュレーションでは, 仮想のC病
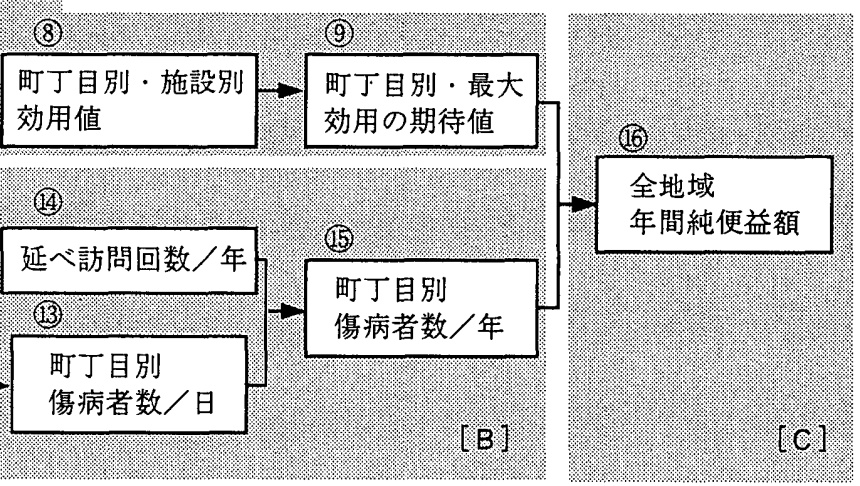
院 (250床) と D病院 (280床) を設定し（合計 63 病院），その 2 病 院が統合して $\mathrm{A} も し く は \mathrm{~B} の$ 候補地に移転する計画（以下，A案， B案)を評価するものとした。また統合後の新病院における病床数 は, C病院と D病院の病床数を併せた 530 床とした。なお便宜的に, 本二次医療圈外加の利用者はないものと仮定した。

表 5 シミュレーションの条件

\begin{tabular}{|l|l|}
\hline \multicolumn{1}{|c|}{ 項 目 } & \multicolumn{1}{c|}{ 想定内容 } \\
\hline 総夜間人口 & $1,219,024$ 人 \\
\hline 総病床数 & 12,078 床 $(991$ 床 $/ 10$ 万人) \\
\hline 病院数 & 61 病院 (平均病床数: 198床) \\
\hline 統合対象病院 & C 病院 (250床) 及びD病院 (280床) \\
\hline 移転後の病床規模 & A 案, B 案ともに530床 \\
\hline
\end{tabular}

註）総病床数，病院数は $\mathrm{C}, \mathrm{D}$ 病院を除く。

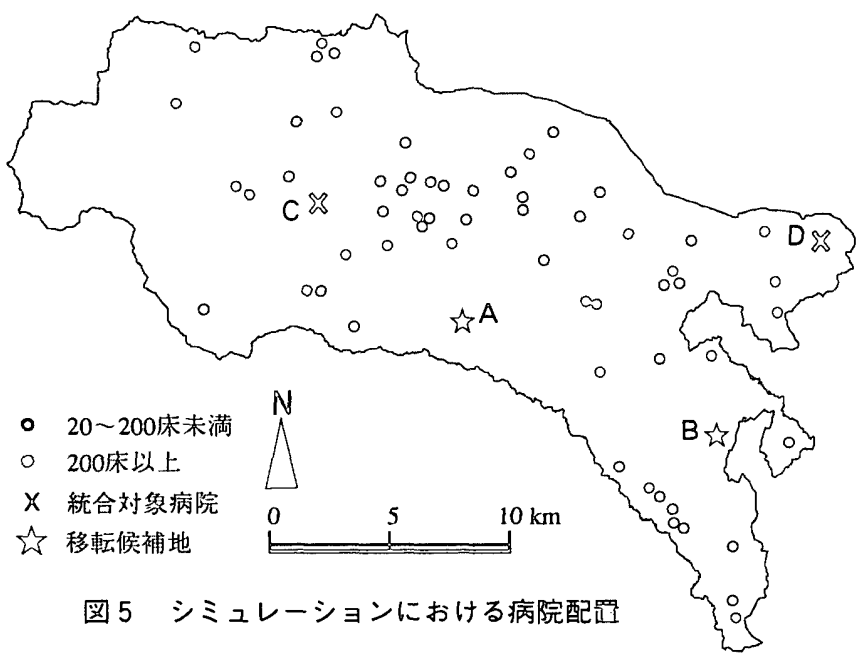

(3) シミュレーション結果

表 6 はA 案，B案のそれぞれに関し，年間の純便益額を示したも のである。地域全体での純便益額は，A 案が2157万円，B案が5476 万円となった。これは 200 床以上の病院が相対的に少ない地域南東 部に移転する $\mathrm{B}$ 案の方が, 大病院も含めて周辺に病院数が多い $\mathrm{A}$ 案 よりも，地域に対してょり大きな便益を与えるためと考えられる。 更に表 6 をタイプ毎に見ると,全タイプでB案の方がA案よりも高 い便益額を示していることがわかる。また $\mathrm{A}$ 案，B案ともに，タイ プ1が唯一，負の便益額となっている。これは，施設選択モデルが タイプ1について，より小規模な病床数の施設を支持する傾向を 持っており，統合による病院の大規模・集約化の一つの影響である と考えられる。更に地区毎に, 現状に対する純便益額の増減率を示 したものが図 6 の（a）（b）である。地域的な特徵を把握しやす くするため, 増減率の表示区分は「-25\%以下」「-25\%超· $25 \%$ 以下」 $\lceil 25 \%$ 超」の 3 段階とした。図 6 より以下の点が指摘できる。

(1)A案，B案共に，移転先とその周辺地区は純便益が正となる。 (2) $\mathrm{A}$ 案, B案共に, 病院の統合で新病院の病床規模が大きくなる ため，移転後の影響範囲は相対的に広い地域に及んでいる。 (3)病院が少ない D地点の周辺エリアは, 移転に伴い, 負の便益と なる地区が広い範囲に及んでいる。逆に，C地点の周辺エリ アは病院が多いため，移転による影響はそれ程大きくない。 ここでは利用者側の便益·費用のみを対象としてシミュレーショ
ンを行い, 前述のようにB案の方が $\mathrm{A}$ 案よりも大きな純便益を発生 させることがわかった。更に，移転に伴って発生する事業者側の費 用便益項目，すなわち地域全体としての総事業収入の增減や用地取 得費，病院スタッフの交通コストを加味することで，A案と B 案の どちらに移転するのが地域にとって有効な施策であるかを最終的に 評価することができる。

\section{5。まとめと今後の㹎題}

本報告では，医療施設の選択行動モデルに対して費用パラメータ を含めたロジットモデルを適用し，種々の公表データを活用しなが ら，病院の配置計画を費用便益的に評価する手法を提案した。更に 事例分析を通じて, 手法の具体的な適用方法を提示した。今後は, 今 回得られた知見を発展させ，以下の事項を行うことが課題である。

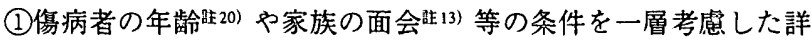
細な追加調査とそれに基づくモデル精度の向上

(2)災害時の病院拠点機能を費用便益的に評価する手法の開発

表 6 傷病別の純便益額（単位：千円）

\begin{tabular}{|r|r|r|r|r|r|r|}
\hline & タイプ1 & タイプ2 & タイプ3 & タイプ4 & タイプ5 & 合 計 \\
\hline $\mathrm{A}$ 案 & $-17,035$ & 15,144 & 6,799 & 4,512 & 12,149 & 21,569 \\
\hline $\mathrm{B}$ 案 & $-12,230$ & 21,223 & 9,850 & 8,515 & 27,402 & 54,760 \\
\hline
\end{tabular}

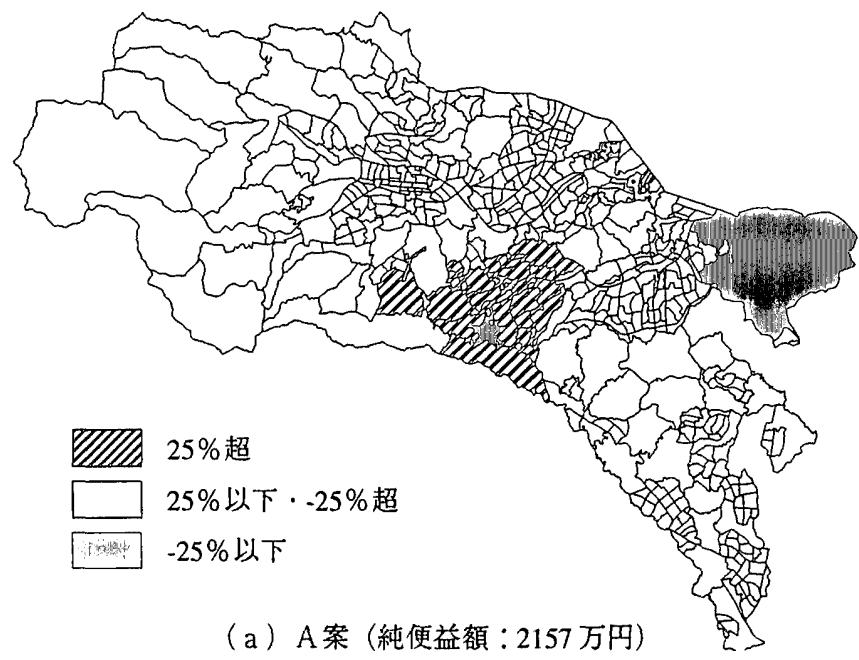

（a）A案（純便益額：2157万円）

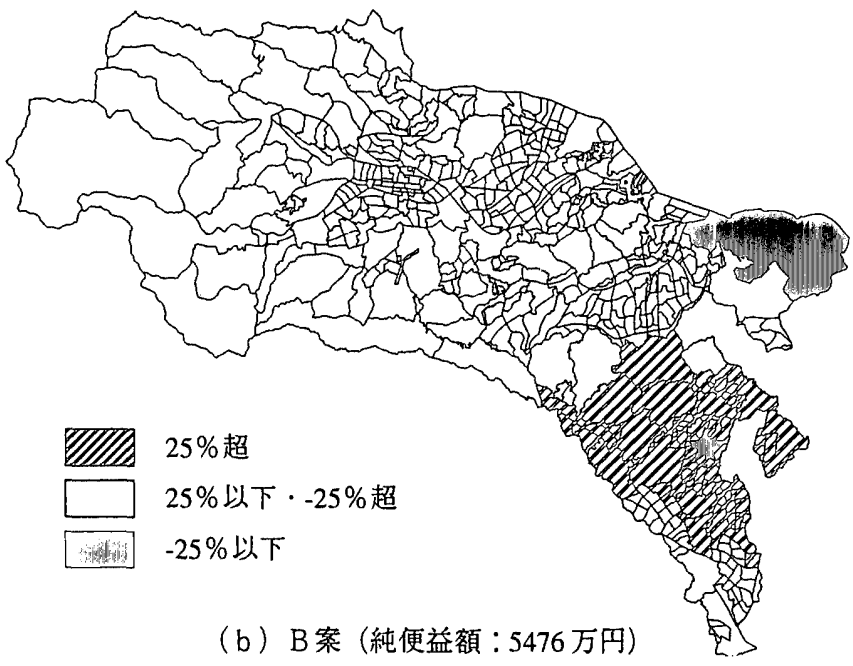

図 6 地区毎の居住者便益の增減状況 
謝辞

本研究を実施するにあたり，便益計測については東北大学・森杉壽芳教 授に，統計解析については文部省統計数理研究所・馬場康維教授よりご助 言を頂きました。アンケートの質問項目に関しては，鹿島建設健康管理セ ンター・山本佳男所長, 桶口義弘事務次長よりご協力を頂戴しました。ま た医療施策の動向等に関しては, 鹿島建設医療福祉チーム・木島曉部長, 安 藤繁次長，成田裕介氏より多くの情報を提供して頂きました。GＩＳ上の 作業では三井造船システム技研・亀田貴雄氏から，コンピュータ上の処理 過程では鹿島建設情報システム部・大西克保氏，技術研究所・中島賢市氏 からアドバイスを頂戴しました。また匿名の査読者からも有益なコメント を頂きました。ここに記して深甚なる謝意を表します。

補註

註 1) 医療法 31 条に定める病院で, 開設者が, (1)都道府県, (2)市町村, (3) その他厚生大臣が指定するものを指す。

註 2 ）例えば厚生省では「原則として二次医療圈每に1ヶ所の地震災害医 療センターを整備する」等を具体的な政策 ${ }^{1)}$ として打ち出している。

註 3 ）費用便益分析 ${ }^{2)} は$ ，全対象項目を貨幣価值に換算して，統一的な尺 度で計画を評価する手法である。

註 4 ）厚生省指針では，二次医療圈とは「一般医療で，主として病院への 入院医療を提供する体制の確保を図る区域」とされている。我国では，既 に都道府県の貴任において地域を細分化し，独自に設定が行われている。

註 5 ）医療法では，病院は「患者 20 人以上の収容施設を有するもの」とさ

れ，療養所やセンターと呼ばれるものも，病床数が 20 床以上あれば病院 の範鰙に含められる。一方，20床未満は診療所の範睰となる。

註6) ロジットモデルの特徵としては，以下の点があげられる。

(1)同じ傷病でも同じ病院に行くとは限らず，確染事象として患者の選択 行動を捉えることができる。

(2)クロ経済学の効用最大化理論から導出されており，採用された变数 と効用値の関係が分析しやすい。

(3)離散量（選択／非選択）を被説明変数とする離散選択モデルの中でパ ラメータの推定が最も容易である。

註 7 ) 平成 7 年より我国でも，世界保健機構の第 10 回修正「国際疾病・傷 害および死因統計分類 (ICD) 」に基づく傷病大分類が採用されている。本 分類項目のうち今回は，まず「精神及び行動の傷害」を除外した。更に， 文献 [21］において受療率が低く，且つ文献 [17］で一日当たりの診療 行為点数の著しく低い項目を分析の対象外とした。また図 2 では，「神経 系の疾患」「眼及び付属器の疾患」及び「耳及び乳様突起の疾患」を「神 経・感覚器」という名称にまとめて表示した。

註 8）傷病分類毎の総診療点数を診療報酬明細書（レセプト）に記載され ている入院あるいは通院日数で除した值。

註 9 ）文献 [18］の補注 1 において，二つの分布を識別する際の不確実性 を表すという点で，類似度の指標である Kullback の情報量とカイ自乗值 は漸近的に検定量として同等であり，カイ自乘値を情報量と代替させて も同様の結果が得られるであろうことが述べられている。

註 10）最長距離法は他の方法と比較して，グループの空間的な広がりの大 きさが極端に相違することがないように分類されるという特徵がある。191 註 11）どの段階で合併をやめれば適正かという問題が発生するが，今回は より数值的な処理でグループ数を決定することとし，グループ間距離の 変化が急激な段階を，グループ数を決めるための判断基準と考えた。 註12)アンケートでは, 回答者が傷病の重さを適切に認識できるように, 下 記の通り，傷病名に症状及び治療内容の目安を併記して質問を行った。
・タイプ1:38度を超える発熱を伴う風邪をひいたが歩くことはできる。 1〜2 回の通院で治りそうだ。(高熱を伴う感冒)

・タイプ 2 :食あたりで腹痛がひどく下瘛が続く。脱水症状のため点滴の 可能性もある。(急性胃腸炎)

・タイプ 3 :検診で糖尿病が見つかった。放置すれば手足のしびれや失明 に慗がる。月 1 回は定期的に通院しなければならない。(糖㽷病) ・タイプ 4 :全身がだるく39度の熱がある。ウイルス性の急性肝炎で1ヶ 月程度の入院が必要だ。(急性肝炎)

・タイプ 5 : 階段から落ちて足首を複雑骨折した。簡単な手術の後, 数週 間の入院が必要だ。(軽微な手術を伴う骨折)

註 13）本条件の提示により，モデルには暗黙的に家族の面会者の効用が含 まれるものと考えた。ただし回答者の意識程度によっては, 効用値が過 小評価される可能性がある。この部分の精緻化は今後の課題であると考 える。

註 14）居住地・医療施設間の交通費は, 便益計測の際に必要となる費用パ

\begin{tabular}{|c|c|}
\hline 䧼病タイプ & 相関値 \\
\hline タイプ 1 & 0.61 \\
\hline タイプ 2 & 0.42 \\
\hline タイプ 3 & 0.47 \\
\hline タイプ 4 & 0.36 \\
\hline タイプ 5 & 0.34 \\
\hline
\end{tabular}

ラメータの説明変数であるが, 移動 距離と同義的であり，モデル作成時 の多重共線性のチエックを行った。 交通費と移動距離に関する相関係数 は左表の通りであり，相関関係が特 に強いとは言えないことを確認した。

註 15）病床規模は，モデル推定において試行を繰り返した結果，表中の区 分値を用いて，診療所，小・中・大規模病院に分けることとした。 註 16）三井造船システム技研より提供されている MapInfo 道路地図データ （1998 年版）に対し，米国 MapInfo 社の MapInfo 4.1，ACT 社の距離計算 パッケージを用いて，GISによる道路距離計測を行った。

註17)回答者毎の施設選択肢に対する交通費は以下の方法により設定した。 (1)アンケート結果を基に，傷病タイプ別の交通機関分担率（\%) をまと めると下表の通りである。ここで表中の徒歩系とは徒歩・自転車，公 共交通系とは鉄道・バス，車系とは自家用車（オートバイを含む）・夕 クシーを指すものとする。

\begin{tabular}{|c|c|c|c|}
\hline タイプ & 徒歩系 & 公共交通系 & 車系 \\
\hline 1 & $53.1 \%$ & $44.0 \%$ & $2.9 \%$ \\
\hline 2 & 35.4 & 12.2 & 52.4 \\
\hline 3 & 29.6 & 65.0 & 5.4 \\
\hline 4 & 19.3 & 7.8 & 72.9 \\
\hline 5 & 17.8 & 8.1 & 74.1 \\
\hline
\end{tabular}

(2)回答者が選択した施設については，回答で得られた交通手段を用いる こととし，それ以外の選択可能施設については，上記の表及び回答結 果の分析から，以下のルールを仮定して交通手段を設定した。

[タイプ1及び3]

·居住地から医療施設までが $1 \mathrm{~km}$ 以内の場合は徒歩系, $1 \mathrm{~km}$ 超の場 合は公共交通系とする。

[タイプ2，4及び5]

・居住地から医療施設までが $500 \mathrm{~m}$ 以内の場合は徒歩系とする。 $500 \mathrm{~m}$ 超の場合, 全タイプのうち何れかで,「自家用車を利用」と回答して いる場合は自家用車，それ以外の場合はタクシーとする。

(3)交通費について，徒歩系は零，公共交通系は鉄道・バスの組み合わせ を考慮した最小交通費とした。自家用車は，ガソリン代を100円／， とし， $8 \mathrm{~km} / \ell の$ 割合で走行可能として算定した。タクシーについて 
は，最初の $2 \mathrm{~km}$ までが 660 円，それを超えると $250 \mathrm{~m}$ 毎に 80 月を加 算するという料金体系を適用した。

(4)上記(2)で設定した交通手段に对し，上記(3)の算定方法を適用して交通 費を算出する。

註 18）複数回答のある施設はそれらの平均値を算出し, 回答のない施設に 対しては, アンケート回答を基に, 表 3 に示した病床規模クラス毎の平 均値を求めて，待ち時間を算定した。

註 19）年齡は，文献 [21］における傷病の受療率, 及びアンケート回答者 数の年齢分布の両面から判断して区分した。

註 20）既往の研究617では, 子供と高龄者の施設選択行動が成人とは異な ることが報告されている。本分析で年齡に関する項目が有意とならな かった理由は, 以下の 2 点が考えられる。

(1)家族全員に対して回答を求めているものの，世带主を中心としたアン ケートの発送であったため，子供や高龄者からの回答が少なかった。 （特に 15 藏未满は 4 件，65藏以上は 14 件の有効回答。）

(2)上記(1)で回答のあった子供及び高齡者について，所属する世帯の全員 が同一施設を選択する傾向が影著に現れている。これは世带を代表す る1名がまとめて回答したためと推察される。

上記既往研究では，特に高龄者は距雖の影響を受けやすいことが示さ れており，今回のモデルを用いた便益計測の場合，地域全体としての数 值に偏りが生じる可能性がある。本研究では，回答者への負担を考感し て追加アンケートの実施を見送ったが，更に年齡条件を考虑したモデル の䄇緻化は今後の課題である。

註21）全ての回帰係数が零であるモデルの下での尤度 $\mathrm{L}_{0}$ と，当てはめたモ デルの $\mathrm{L}_{1}$ とを直接比較して、下式によりカイ自乗統計量を計算した。 $\chi^{2}=-2\left[\log \left(\mathrm{L}_{0}\right)-\log \left(\mathrm{L}_{1}\right)\right]$

註22）本シミュレーションでは，特に以下の仮定を設定した。

(1)モデルに対する医療施設の選択肢集合について，タイプ1及び2は回 答者の属する市区町村に立地する全一般病院を，タイプ3〜 5は回答 者の属する二次医療圈内の全一般病院を基本とした。更にタイプ1 3 では，3章のアンケート結果を参考にして，各地区の重心から 800, $1200,1500 \mathrm{~m}$ の各距離に選択対象となる20本末満の䛦療所が存在する ものと仮定し，その 3 診療所を上記該当タイプの選択肢集合に加えた。 (2)各居住地から選択可能施設までの往復交通費は，註 17）のルールを用

\begin{tabular}{|c|c|c|}
\hline タイプ & 自家用車 & タクシー \\
\hline 2 & $71.8 \%$ & $28.2 \%$ \\
\hline 4 & 64.4 & 35.6 \\
\hline 5 & 68.3 & 31.7 \\
\hline
\end{tabular}

いて算定した。ただし，タイ プ2，4，5に対する自家用 車とタクシーの手段選択に は, アンケート結果に基づく 下表の分担率を用い,OD間に おける各々の交通費に重み付けをして平均往復交通費を算出した。

(3)医療施設の待ち時間は，施設選択行動の結果である来院患者数の集中 度合いによって影響を受けるため, 待ち時間の增減を加味して来院患 者数の均衡状態を求めるという分析も行った。その結果, 効用値に対 する待ち時間增減の影響は, 極めて小さいことが確認できた。従って, ここでは「来院患者数の增減に係わらず待ち時間は一定である」とし て註 18）の方法を採った。

\section{参考文献}

1) 阪神・淡路大震災を契機とした災害医療体制のあり方に関する研究会: 平成 7 年度厚生科学研究費補助金健康政策調查研究事業「研究報告 青」, 厚生省, pp.38-39，1996 年 4 月

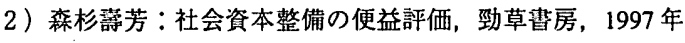

3 ) 谷村秀彦, 暒秀樹, 池田三郎, 腰塚武志: 都市計画数理, 朝倉出版, 1986 年

4) 柏原士郎：地域施設計画論, 鹿島出版会, 1991 年

5) Morris Cohen, Hau Lee: Hospital attractiveness as a determinant of regional hospital market shares, Proc. 10th Int. Conf., Operational Research, pp.10321046,1984

6) 佐䑏平, 長沢悟, 谷村秀彦, 廣川協一: 患者の病院選択行動に関する ロジット分析, 日本大学工学部紀要, 第 32 巻, pp.85-102, 1991 年 3 月

7) モンデェ・アシシア, 谷村秀彦, 菲森敦：人口の高齡化を考虑した一 般病床数再配分方法の提案, 日本建築学会計画系論文集, 第 485 号, pp.157-162，1996年 7 月

8）青不義次, 村岡直人: 遗伝的アルゴリズムを用いた地域施設配置手法, 日本建築学会計画系論文集，第 484 号，pp.129-135，1996 年 6 月

9 ) 山下剛，友清貴和：遗伝的アルゴリズムを用いた高齡者在宅福杫サー ビス供給の最適化手法試案, 日本建築学会計画系論文集, 第 509 号, pp.105-112，1998 年 7 月

10）横田隆司：高龄者福祉施設の適正配置計画への DEA モデルの適用性の 検討, 日本建築学会計画系論文集，第 523 号, pp.189-194, 1999 年 9 月

11）横田隆司：一般病院の適正配圈計画への多目的計画法の適用性につい て (1), 日本建築学会計画系論文集, 第 411 号, pp.25-34，1990年 5 月

12）横田隆司：一般病院の適正配置計画への多目的計画法の適用性（2）, 日本建築学会計画系論文集, 第 417 号, pp.43-50，1990年 11 月

13) Maddala, G.S.:Limited dependent and qualitative variables in econometrics, Cambridge University Press, 1983

14) 土木学会土木計画学研究委貝会: 非集計行動モデルの理論と実際, (社) 土木学会, 1995 年

15）森杉壽芳, 由利昌平 : ランダム効用理論に基づく住環境便益の定義と その測定方法について, 土木学会土木計画学研究・講演集, 10 号, pp.267-273, 1987 年

16）屋井鉄雄, 岩倉成志, 伊藤誠 : 鉄道ネットワークの需要と余剩の推計 法について, 土木学会土木計画学研究·論文集, 11 号, pp.81-88, 1993 年 12 月

17）厚生省大臣官房統計情報部編：平成 9 年 - 杜会医療診療行為別調査報 告 (上巻- 全国・診療行為大分類)，(財) 厚生統計協会，1999年 6 月

18）谷村秀彦，廣川協一，葴森敦：情報量クラスター分析に上る医療圈域 の階層構造の把握, 日本建築学会計画系論文集, 第 370号, pp.13-20, 1986 年 12 月

19）松本直司：類型化するくクラスター分析〉，建筑・都市計画分野のた めの調查・分析方法, 井上昦院, pp.152-157，1987 年 4月

20）厚生省健康政策研究会編：病院要覧，医学昇院，1997 年

21）厚生省大臣官房統計情報部編: 平成 8 年-患者調査 (中巻-都道府県編), （財）厚生統計協会, 1999 年 1 月

(1999年11月 10 日原稿受理，2000年 4 月 3 日採用決定） 